\title{
RUANG REKREASI MUSIK DI PAPANGGO, TANJUNG PRIOK
}

\author{
Nicholas Antonio ${ }^{1)}$, Martin Halim ${ }^{2)}$ \\ 1)Program Studi S1 Arsitektur, Fakultas Teknik, Universitas Tarumanagara, \\ nicholasantonio18@gmail.com \\ 2)Program Studi S1 Arsitektur, Fakultas Teknik, Universitas Tarumanagara, martinhalim90@gmail.com
}

Masuk: 13-07-2020, revisi: 31-07-2020, diterima untuk diterbitkan: 24-09-2020

\begin{abstract}
Abstrak
Didapati bahwa daerah Jakarta Utara memiliki tingkat partisipasi Angkatan kerja yang cukup tinggi. Kondisi tersebut ternyata banyak menimbulkan terjadinya stress pada masyarakat. Menurut data BPS Jakarta Utara, Angkatan kerja di Tanjung Priok mencapai 66\% dan selebihnya merupakan bagian dari bukan angkatan kerja. Bisa disimpulkan lewat data ini bahwa hampir seluruh lapisan masyarakat daerah Jakarta Utara memiliki pekerjaan. Dengan adanya perubahan-perubahan dari teknologi manual menjadi teknologi tinggi. Melalui keadaan tersebutlah yang membuat masyarakat harus mengalami revolusi teknologi yang sebetulnya belum siap untuk dihadapi oleh masyarakat. "Mengapa musik dipakai sebagai media untuk mengurangi tingkat jenuh seseorang?" Menurut penelitian British Journal of Phsychiatrist, dalam jurnal ini dipaparkan bahwa musik berdampak baik untuk berbagai macam gangguan kesehatan, dan musik juga merupakan media yang dapat mengurangi tingkat jenuh seseorang. "Music Is Liquid Architecture, Architecture Is Frozen Music" - Johann Wolfgang von Goethe. Adapun nilai utama yang memfasilitasi proyek ini yaitu rekreasi musik dan jajanan makanan jalanan yang berhubungan dengan relaksasi serta menghilangkan jenuh sebagai bagian dari respon masalah yang dialami masyarakat. Jadi sebagai solusi untuk mengurangi tingkat jenuh pada saat bekerja, yaitu menyediakan wadah berupa ruang perantara, antara first place dan second place dalam bentuk rekreasi musik dan kuliner jalanan.
\end{abstract}

\section{Kata kunci: Angkatan Kerja; Musik; Rekreasi}

\begin{abstract}
It was found in the area of North Jakarta has a fairly high level of labor force participation. It can be concluded from this data that all levels of society in North Jakarta have jobs. With the changes from manual technology to high technology, It is through these circumstances that people must revolutionize technology that's actually not ready to be faced by the community. This condition creates a lot of pressure on the community. According to North Jakarta BPS data, the labor force in Tanjung Priok reaches $66 \%$ and the rest are part of the non-workforce. So, the solution to reduce the level of saturation at work, namely providing a place for intermediary space, between the first and second places in the form of music and culinary recreation. "Why is music used as a medium to reduce one's level of saturation?" According to research by the British Journal of Psychiatrist, this journal describes that music good for a variety of health problems, and music is also a medium that can reduce one's saturation level. "Music Is Liquid Architecture, Architecture Is Frozen Music" Johann Wolfgang von Goethe. As the main values that facilitate the project are music recreation and street food snacks that related to relaxation and eliminating saturation as part of the response to problems experienced by the community.
\end{abstract}

\section{Keywords: Labor Force; Music; Recreation}




\section{PENDAHULUAN}

\section{Latar Belakang}

Menurut data BPS kota Jakarta Utara, konsekuensi tinggal di kota besar seperti Jakarta ini salah satunya adalah berurusan dengan stress. Kondisi kota yang padat, ramai dan segalanya berjalan serba cepat membuat masyarakat berhubungan dengan urusan permasalahan stress. Stress biasanya ditunjukan sebagai bentuk kelelahan, kegelisahan dan depresi seseorang. Akibat dari permasalahan tersebut, Jakarta disebut-sebut sebagai kota yang rawan membuat penduduknya stress. Hal ini dikarenakan Jakarta minim sekali fasilitas umum yang mengakibatkan terjadinya ketegangan sosial. Sebagai makhluk sosial, manusia membutuhkan interaksi-interaksi sosial dengan sesamanya. Dimana dengan saling bertemu dan bertukar pendapat secara langsung bisa menjadi salah satu obat dari stress tersebut.

Hasil penelitian menunjukkan bahwa stres berpengaruh negatif, baik terhadap fisik maupun psikologis. Pada umumnya, masyarakat berpikir bahwa stress merupakan hal yang biasa saja seperti jadwal kerja yang padat dan melelahkan atau konflik dengan sesama. Dengan melakukan pencegahan dengan mendengarkan musik maka dari itu, dibutuhkan suatu wadah tempat masyarakat untuk bertemu secara langsung disertai dengan kegiatan-kegiatan yang membangun dan nantinya bisa menjadi suatu tempat untuk bertukar pikiran. Disisi lain, ruang ini juga mempunyai sifat mengajak masyarakat untuk belajar betapa pentingnya peranan musik dalam melakukan pencegahan berbagai macam penyakit khususnya masalah kesehatan mental yang sering terjadi di kota Jakarta ini.

\section{Rumusan Permasalahan}

Pada survey lapangan yang dilakukan, ditemukan bahwa daerah Tanjung Priok khusus nya wilayah Papanggo ini merupakan daerah yang masih minim ruang sehat untuk bersosialisasi atau masih terbilang masih minim area untuk berekreasi dengan tujuan menghilangkan penat saat selesai kerja. arsitektur bisa menjadi wadah yang dapat memfasilitasi permasalahan penyakit mental yang dialami oleh masyarakat sekitar dengan penanganan yang diperlukan masyarakat dalam bentuk rekreasi musik sebagai inti jawaban dari permasalahan yang ada di tengah masyarakat.

\section{Tujuan}

Dengan didasari permasalahan diatas, maka proyek dibentuk dengan tujuan meminimalisir tingkat stress yang ada di wilayah tersebut serta memperkenalkan musik dengan cara yang berbeda yaitu sebagai media untuk menghilangkan penat dan stress yang dialami oleh seseorang, serta memfasilitasi masyarakat dengan adanya akses ruang berkumpul yang interaktif dan bersifat menyenangkan, dengan memberikan manfaat berupa edukasi bermusik yang dapat dijadikan sebagai terapi ringan untuk menghilangkan kepenatan.

\section{KAJIAN LITERATUR}

Kajian teoritis yang akan diambil adalah teori-teori yang akan digunakan dalam mendukung proses penelitian, sebagai acuan yang dibuat bukan dari hasil karangan, tetapi hasil karya ilmiah yang dapat dipertangung-jawabkan kebenarannya.

\section{Architecture Third Place}

Open Architecture, the architecture for third place atau disebut juga sebagai ruang ketiga, merupakan ruang yang diperuntukan untuk bersosialisasi dengan masyarakat lainnya. sebagai bentuk pergerakan masyarakat dari tempat pertama yang biasa disebut rumah dan juga tempat kedua sebagai tempat kerja. Third place adalah tempat yang bersifat openness, yang dimana siapapun dapat mengaksesnya sebagai tempat aktivitas yang digunakan oleh kalangan manapun. Third place sering kali memiliki bentuk yang bermacam - macam sesuai dengan 
kebutuhan masyarakat sekitarnya. Nilai - nilai Open architecture, the archtiecture for third place menurut Ray Oldenburg (1999) yang memiliki sifat Neutral, Suatu lingkungan memang harus mempunyai tempat yang netral, karena jika tidak ada maka akan terjadi kesenjangan sosial antar masyarakat. Tempat netral ini diharapkan bisa menjadi tempat yang lebih informal dan intim sekaligus menjadi tempat yang dapat memberikan kesenangan untuk semua kalangan masyarakat. Leveler, Third Place harus bisa melawan kecenderungan dalam pembatasan derajat seseorang dan harus bisa lebih bersifat sama rata dengan yang lainnya.

Low Profile, Third place juga harus bisa melengkapi kesenjangan sosial ini dengan mengedepankan poin equality dan inclusivity. Accessibility and accommodation, Third place memang seharusnya bisa diakses oleh orang, Di mana "third place" yang produktif di area perlintasan perkotaan, sehingga orang-orang mungkin dapat menikmati insting sosial mereka sebagai pilihan. A home away from home, Daya Tarik sebuah third place bergantung pada program dan aktivitas yang ada dalam suatu proyek. Pengunjung tetap menjadikan tempat tersebut berkarakter dan seringkali berasumsi bahwa third place ini harus bisa menjadi pusat perhatian.Conversation is the main activity, Biasanya orang terlalu serius dengan personal space nya sendiri dan bersifat individualistis dan tidak akan bisa bertahan terlalu lama di tempat ini. Dalam proyek ini sifat tersebut harus dihilangkan dan sebisa mungkin bisa memberikan kebersamaan setiap individu sehingga sifat kecemasan dan keterasingan tidak terlihat dalam proyek ini. Dengan melakukan pertukaran informasi dengan setiap individu, maka sifat keterasingan bisa diminimalisir.

\section{Rekreasi}

Menurut Journal of Physical Education, Recreation \& Dance, Rekreasi adalah kegiatan yang menyehatkan pada aspek sosial, fisik dan mental. Aktivitas rekreasi adalah pelengkap dari kerja, oleh karena itu rekreasi adalah kebutuhan semua orang. Dengan demikian, penekanan arti dari aktivitas rekreasi adalah aktivitas dengan nuansa "menciptakan kembali" (recreation) orang tersebut, dengan upaya merevitalisasi jiwa dan tubuh yang terhindar dari kegiatan rutin dan kondisi yang tertekan dalam kehidupan sehari-hari.

\section{Terapi Musik}

Menurut Yinger (2017 dalam Geraldina, 2017), Terapi musik adalah usaha meningkatkan kualitas fisik dan mental dengan rangsangan suara yang terdiri dari melodi, ritme, harmoni, timbre, bentuk dan gaya yang di organisir sedemikian rupa sehingga mencipta musik yang bermanfaat untuk kesehatan fisik dan mental. Musik memiliki kekuatan untuk mengobati penyakit dan meningkatkan kemampuan pikiran seseorang. Musik diharapkan menjadi sebuah terapi dan musik dapat meningkatkan, memulihkan, memelihara kesehatan fisik, mental, emosional, sosial dan spiritual. Hal ini disebabkan musik memiliki beberapa kelebihan, yaitu karena musik bersifat nyaman, menenangkan, membuat rileks, berstruktur, dan universal. Terapi musik adalah terapi yang universal dan bisa diterima oleh semua orang karena kita tidak membutuhkan kerja otak yang berat untuk menginterpretasi alunan musik.

\section{Food Street}

Jajanan jalanan atau makanan jalanan adalah makanan atau minuman siap santap yang dijual oleh penjaja jalanan, pedagang asongan, warung, atau kedai di tempat umum, misalnya di tepi jalan umum, pasar, pasar malam, atau pekan raya. Jajanan jalanan biasanya dijajakan di kios makanan, gerobak makanan, atau truk makanan dan dimaksudkan sebagai makanan segera dikonsumsi. Beberapa makanan jalanan bersifat lokal, beberapa jenis makanan lebih populer dan melampaui batas wilayah tradisional mereka. Beberapa jajanan jalanan diklasifikasikan sebagai camilan dan makanan cepat saji, dan rata-rata lebih murah daripada harga makanan di rumah makan. Menurut penelitian yang digelar pada 2007 study dari Food and Agriculture Organization, 2,5 miliar orang mengkonsumsi jajanan jalanan setiap hari. 


\section{Biophilic Design}

Berdasarkan TERRAPIN Bright Green dalam jurnalnya yang berjudul Patterns of Biophilic Design. Biophilia dalam konteks terlihat sebagai evolusi biophilic design dalam arsitektur dan perencanaan dan menyajikan kerangka untuk menghubungkan ilmu biologi manusia dan alam. Pertimbangan desain mengeksplorasi contoh faktor (misalnya, skala, iklim, demografi pengguna) yang dapat mempengaruhi keputusan biophilic design untuk membawa kejelasan mengapa beberapa intervensi yang ditiru dan mengapa orang lain mungkin tidak. Pendekatan ini bertujuan bagaimana membantu meredakan stress dengan mendekatkan diri ke alam.

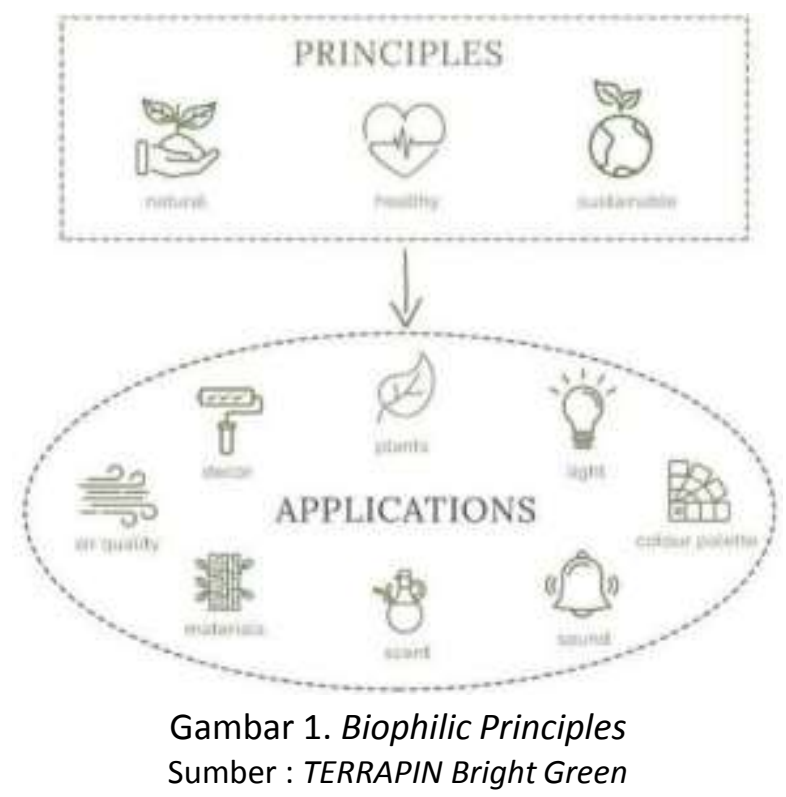

Penerapan beberapa pola-pola biophilic design pada rancangan yang memiliki poin yaitu, Visual Connestion with Nature, Pola ini diterapkan pada objek rancangan yang berupa banyaknya bukaan dan transparannsi yang mempermudah akses visual dari dalam bangunan ke area taman. Sehingga meskipun orang berada di dalam bangunan tetap dapat merasakan secara visual suasana alam yang dihadirkan. Non Visual Connection with Nature, Menghadirkan elemen-elemen alam ke dalam objek rancangan sebagai penerapan pola ini. Elemen-elemen yang dihadirkan seperti tanaman-tanaman air bebatuan dan juga konsisi yang terbuka sehingga orang dapat bersentuhan atau merasakan secara langsung. Presence of Water, Menghadirkan unsur air ke dalam objek rancangan. Di beberapa bagian ditempatkan kolam-kolam dan air mancur sebagai penerapan pola ini. Dynamic \& Diffuse Light, Pola ini diterapkan dengan banyaknya bukaan dan transparansi pada objek rancangan. Bertujuan untuk akses masuk cahaya alamai ke dalam bangunan sehingga suasana alam akan lebih terasa. Selain ini juga bertujuan untuk penghematan energy yang digunakan. Connection with Natural System, Pola ini diterapkan pada area taman-taman yang terbuka sehingga orang dapat merasakan dan menyatu dengan konsisi alam secara langsung. Material Connection with Nature, Penerapan pola ini pada obje rancangan berupa penggunaan material-material yang berasal dari alam seperti kayu, batu, tanah dan lain-lain.

\section{METODE}

\section{Metode Penelitian (Pengumpulan Data)}

Pada saat dilakukannya perancangan, penulis melakukan pengumpulan data sebagai hasil dari metode perancangan yang berupa data eksisiting sekitaran tapak serta perkara permasalahan dari isu yang terjadi dalam masyarakat. Dengan dilakukannya metode pengumpulan data dari hasil survey lapangan, studi literatur maupun studi preseden maka data tersebut bisa diolah dan dianlisis untuk menghasilkan bentukan proyek yang akan dirancang. 


\section{Data Penelitian}

Data Primer didapatkan berdasarkan dari hasil survey yang dilakukan sepanjang jalan sekitaran lokasi tapak dengan melakukan perjalanan dari titik halte transjakarta terdekat sampai titik lokasi tapak. Survey dimulai dari pendataan terlebih dahulu secara visual maupun non-visual dengan mengkaji elemen-elemen pembentuk kota dan mengamati aktivitas-aktivitas masyarakat di daerah tapak. Data sekunder didapatkan dari hasil studi yang dilakukan melalui studi-studi berupa, Studi Literatur dengan melakukan pendataan teori-teori melalui buku dan internet terkait dengan isu permasalahan proyek. Data yang didapat akhirnya dikaji ulang dan dijadikan sebagai skema berpikir saat proses perancangan. Studi Preseden dengan melakukan studi melalui bangunan-bangunan sejenis secara penerapan konsep guna untuk mengetahui kebutuhan ruang yang akan dirancang nantinya. Preseden yang didapat akhirnya dibandingkan satu sama lain dan dinilai mulai dari efisiensi, keunikan, serta keterkaitan nya dengan isu. Lalu kemudian data yang dikaju dijadikan sebagai acuan dalam mendesain proyek.

\section{Metode Perancangan Hybrid Architecture}

Data-data dari sumber yang didapat akhirnya diolah dan dianalisis dengan menggunakan metode perancangan Hybrid Architecture yang dimana membuat sebuah program dengan cara menggabungkan berbagai macam program baru yang kemudian diterapkan dalam proses desain. Menurut Jencks (1997), Metode hybrid dinyatakan melalui tahapan-tahapan quatation, manipulasi elemen, unifikasi dan penggabungan. Tahapan-tahapan dari metode Hybrid ini adalah sebagai berikut, Quotation, artinya menelusuri dan memilih bentuk dan elemen arsitektur yang dianggap potensial untuk diangkat kembali. Manipulasi dan Reduksi Hasil dari quotation tersebut selanjutnya dimanipulasi atau dimodifikasi dengan cara-cara yang dapat menggeser, mengubah, dan atau memutar-balikan makna yang telah ada. Penggabungan dan penyatuan beberapa elemen yang telah dimanipulasi atau dimodifikasi ke dalam desain.

\section{DISKUSI DAN HASIL}

\section{Kawasan dan Tapak}

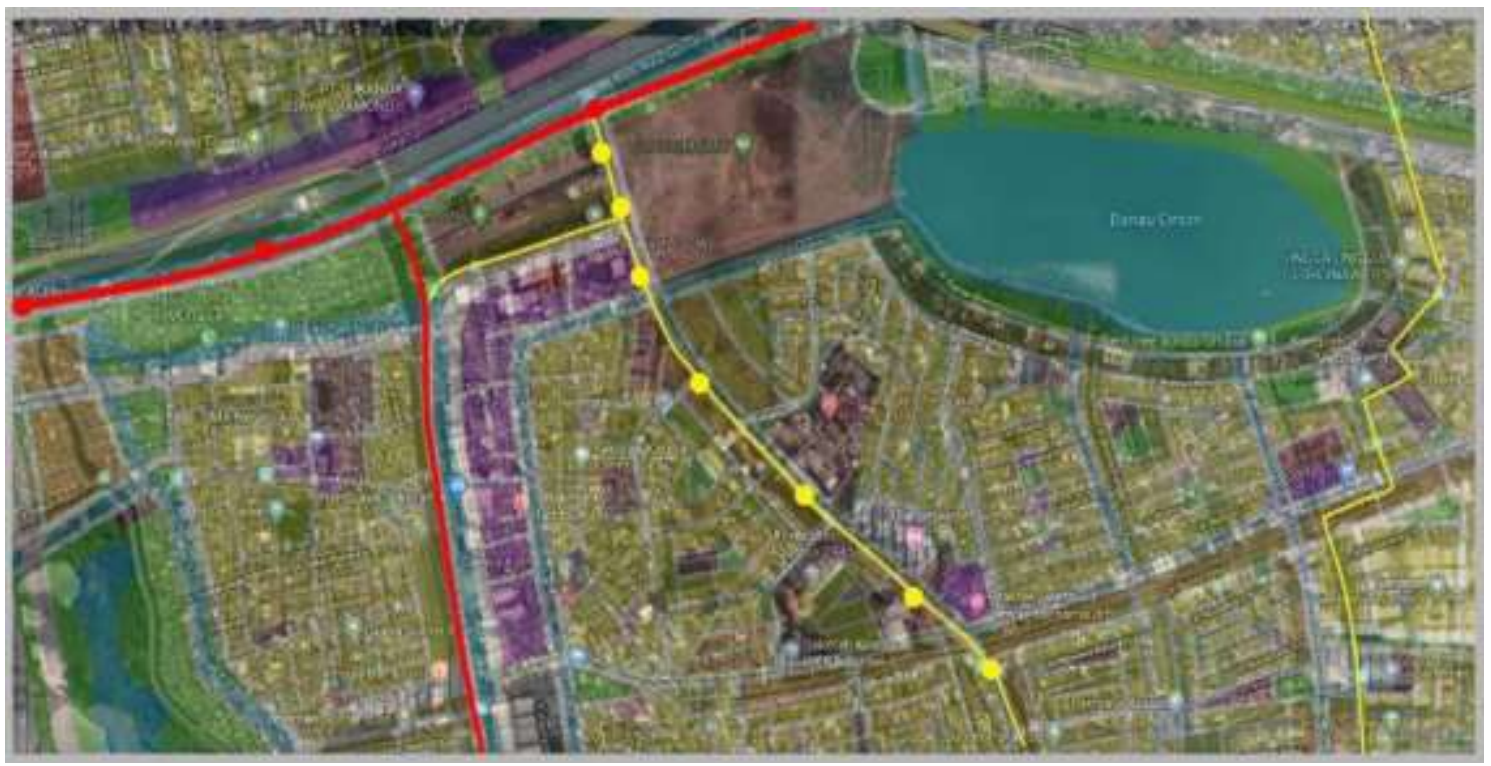

Gambar 2. Moda Transportasi umum daerah Papanggo

Sumber : Peta Jakartasatu yang diolah oleh Penulis

Salah satu tujuan dari proyek ini adalah mengajak masyarakat untuk tidak menghiraukan kekuatiran mereka akan situasi kehidupan yang masyarakat sedang alami. Kemudahan pencapain dari dan ke 
tapak menjadi kriteria utama pemilihan tapak. Didukungnya moda transportasi yang cukup banyak, daerah ini mengalami revitalisasi kawasan yang cukup banyak dilakukan oleh Pemda setempat. Dengan adanya penambahan Transjakarta yang bergerak ke seluruh penjuru Jakarta, memungkinkan untuk daerah ini melakukan suatu pertumbuhan ekonomi yang sangat cepat.

Tapak terpilih merupakan kawasan yang sangat dekat dengan kawasan persekolahan dan bisa dijadikan sebagai point interest \& landmark baru pada kawasan Papanggo, Tanjung Priok. Tapak juga didominasi dengan first place \& second place yang berupa persekolahan serta perniagaan. Melalui kondisi tapak dengan keterkaitan isu, lalu disertakan aspek pemilihan seperti pergerakan manusia yang cukup tinggi \& padat, maka memungkinkan untuk menumbuhkan lokalitas daerah tersebut dengan menghadirkan suatu landmark baru pada kawasan ini.

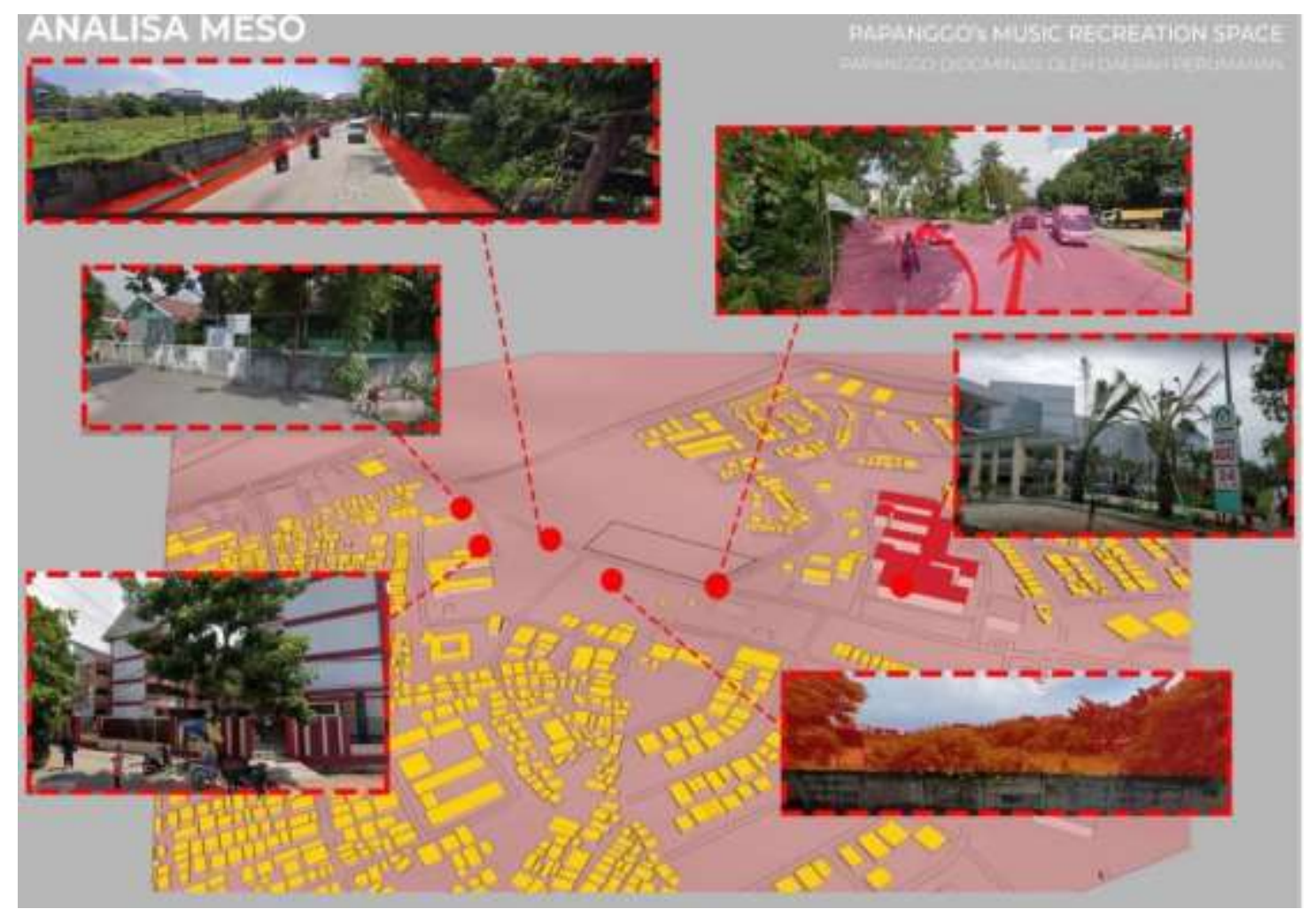

Gambar 3. Kawasan Persekolahan \& Hunian

Sumber : Peta Jakartasatu yang diolah oleh Penulis

\section{Respon Proyek Terhadap Tapak}

Universalitas yang dimiliki musik merupakan salah satu alasan mengapa musik dikembangkan menjadi sarana terapi pada akhirnya. Musik digunakan untuk menghadirkan situasi yang diinginkan, musik digunakan untuk membangun komunikasi dengan pendengar bahkan melalui jalur non-verbal dalam terapi, musik bahkan juga digunakan untuk menghadirkan emosi-emosi positif dan mengurangi emosi-emosi negatif. Pada rancangan fasilitas rekreasi ini, fasilitas sebisa mungkin dapat membantu kota untuk menghadirkan suatu wadah yang dapat membangun sosialisasi antar berbagai tingkat kalangan masyarakat, Dengan merancang proyek rekreasi yang dapat menurunkan tingkat stress seseorang, rancangan ini dapat memaksimalkan diri dengan menghadirkan nuansa alam pada konsep perancangan yang akan dilakukan. Program yang diangkat, yakni menghadirkan public space yang dapat menampung berbagai macam 
individu pada saat mereka sudah selesai melakukan aktivitas. Dengan isu terkait ini, penulis memiliki latar belakang desain yakni, bagaimana mengaplikasikan musik ke dalam suatu arsitektur sebagai elemen penting pembentuknya, penulis membawa latar belakang ini dari pengamatan keseharian yang ada pada kondisi tapak.

Dengan menghadirkan nuansa alam pada setiap segi perancangan, dapat dipastikan proyek ini dapat menjadi wadah bagi orang-orang yang ingin menghilangkan rasa penat pada saat melakukan aktivitas. Diikuti dengan alunan musik instrumental dan suara-suara yang berasal dari alam yang mampu memberikan nilai tambah pada proyek. Diawali dengan memasuki area rancangan yang disambut dengan Garden Street Walk dan area pepohonan yang cukup rindang, masyarakat seakan- akan dibawa kedimensi lain dari kota Jakarta, pada area outdoor dijadikan sebagai area Outdoor Music Stage yang dimana area ini merupakan wadah para pemusik dan masyarakat menikmati suatu karya seni musik dan menjadikan suatu musik sebagai pemersatu antara satu dengan yang lain, disamping itu terdapat food street area yang dimana area ini dapat menampung para pedagang kaki lima agar tidak berjualan secara liar, dan dengan didukungnya fasilitas live music area, area ini akan menjadi titik kumpul bagi masyarakat sekitar setiap harinya.

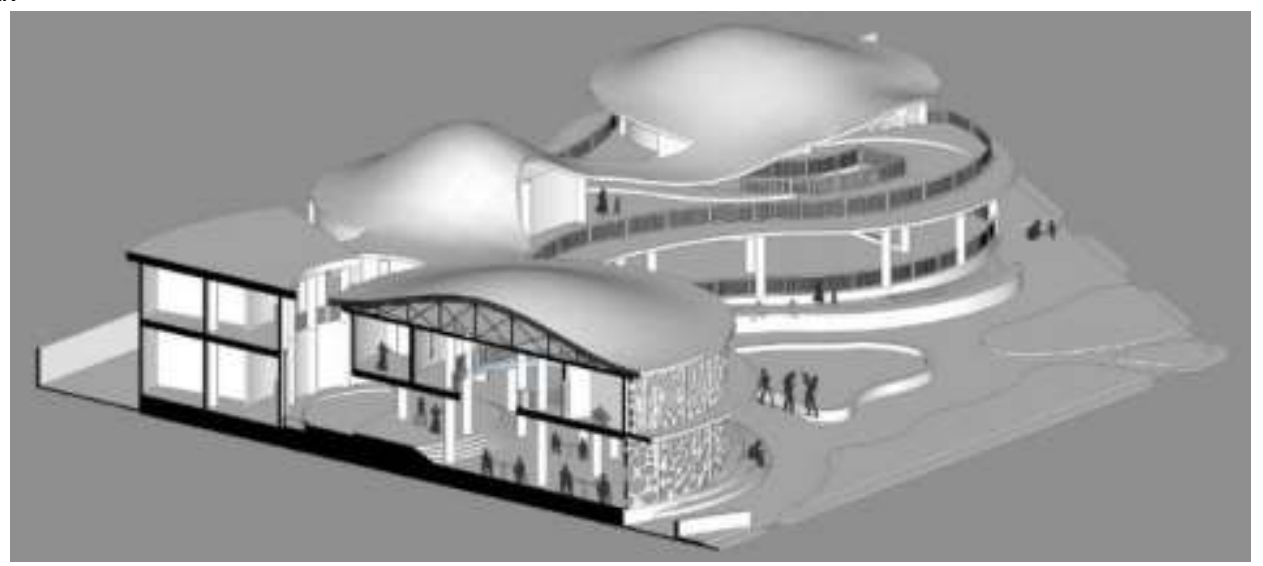

Gambar 4. Skema Aktivitas pada bangunan

Sumber : Penulis, 2020

Diadakan nya Music Audial Space yang menjadi peran utama dalam rancangan proyek, area ini akan menjadi daya tarik tersendiri bagi proyek yang akan dibangun. Pada area ini pengguna ruang akan dibawa ke berbagai tempat didunia dengan menggunakan bantuan rekayasa digital lewat panel- panel LCD yang menyelimuti setiap ruang dan musik instrumental alam yang akan membuat hati tenang.

\section{Penerapan Konsep Biophilic Design pada Proyek}

Untuk konsep desain yang akan diterapkan pada proyek, bangunan proyek ini mengedepankan yang namanya konsep Biophilic Design yang dimana terdapat 2 poin penting dalam pengembangannya yakni Visual \& Non-Visual Connection with Nature, serta Presence of Water Dynamic with Diffuse Light.

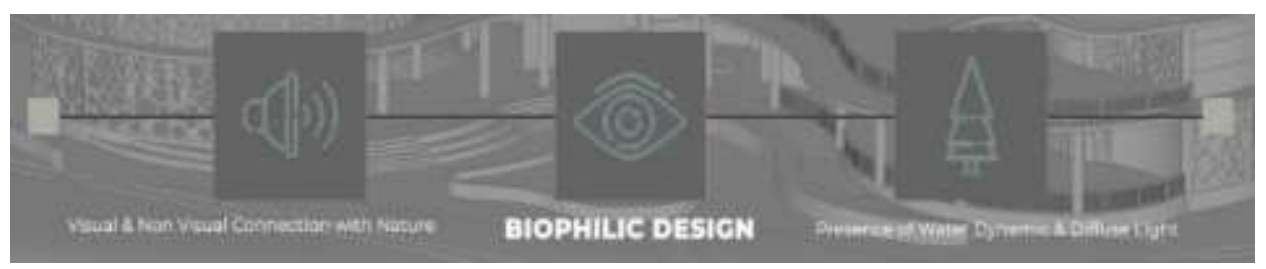

Gambar 5. Biophilic Design Concept

Sumber : TERRAPIN Bright Green diolah oleh penulis 
Pada bagian Accessible Entrance, area entrance bangunan dapat diakses dari dua arah yaitu Jalan. Sunter Permai Raya \& Jalan. Utama 1, yang dimana pada jalan ini merupakan jalan yang dipadati oleh masyarakat.

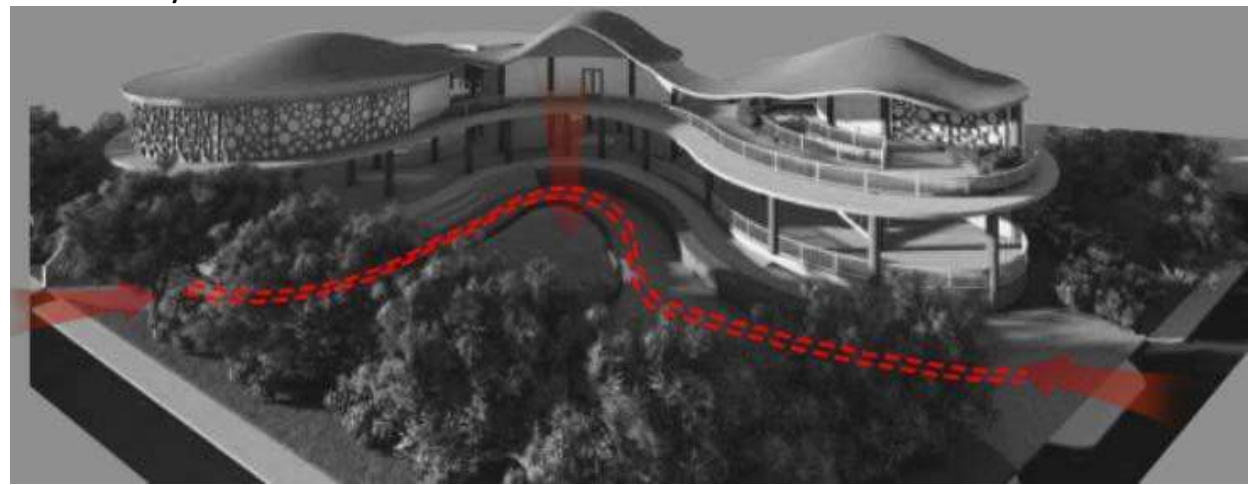

Gambar 6. Analisis Entrance

Sumber : Penulis, 2020

Dari kedua jalan tersebut akhirnya dibukalah dua entrance. Dari kedua entrance tersebut akhirnya dijadikan sebagai titik kumpul baru yang bermuara langsung pada bagian Outdoor Music Stage \& Garden Street Walk. Untuk mendukung konsep desain dari pada Biophilic Design, bangunan ini akan menghadirkan kolam pada area Garden Street Walk serta vegetasi yang menjadi nilai plus dalam perancangan proyek. Dinding beton cetak yang dipakai nanti nya akan diberi lubang-lubang untuk memudahkan cahaya dari luar masuk pada bangunan, dan dinding ini akan memberikan kehadiran Diffuse Light sebagai bukti nyata dari pengembangan konsep Biophilic Design ini.

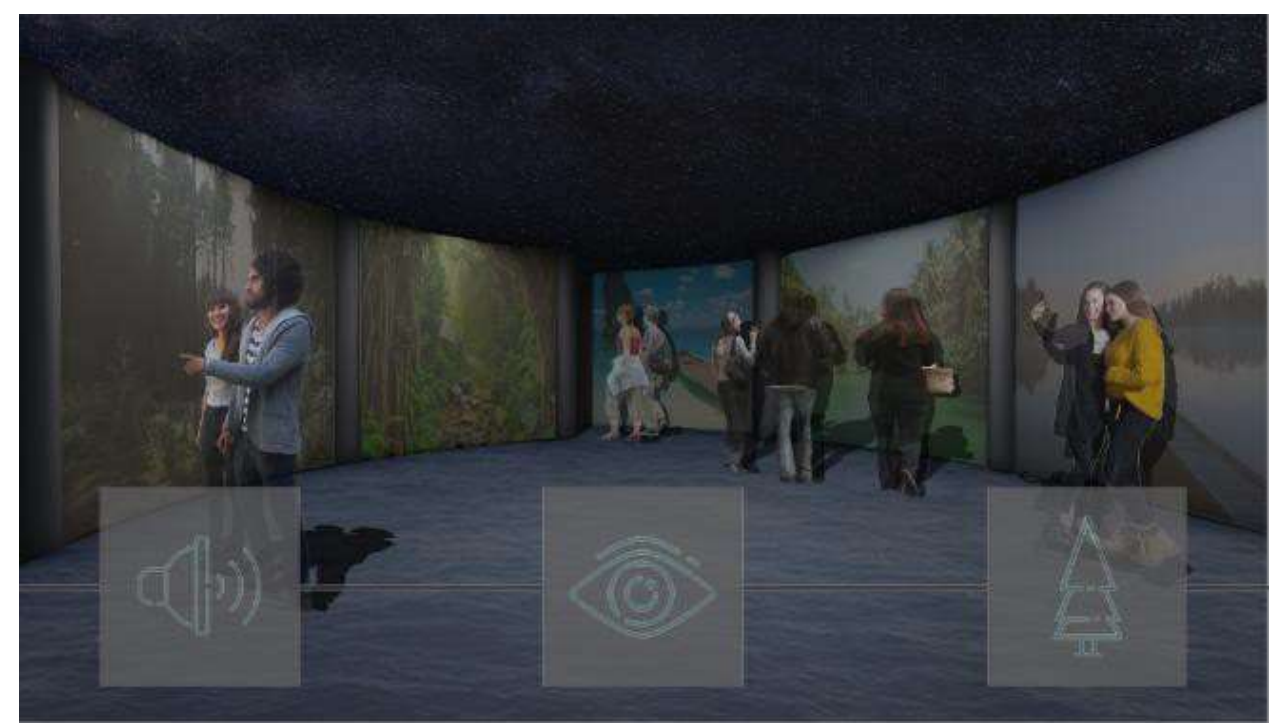

Gambar 7. Audial Space Room

Sumber : Penulis, 2020

Sementara itu pada bagian Audial Space, ruangan ini akan menggunakan konsep The Seven Realms, konsep ini berlatarbelakang adanya penggabungan berbagai macam suasana alam di segala penjuru dunia, dengan cara memasukan rekayasa visual dengan dibantu panel LCD Digital yang menampilkan suasana alam. Ruangan ini sebisa mungkin dapat memberikan pengalaman ruang yang bersifat secara Healing Mentality yang bagus untuk user ruang, serta jenis suara instrumental yang akan dimasukan ke dalam ruangan ini yaitu suara-suara alam yang dapat mendukung pengalaman ruang Audial Space ini seperti suara instrument angin, air, kicauan burung, serta bunyi-bunyi yang dapat menenangkan jiwa. 


\section{Programatik Aktivitas pada Proyek}

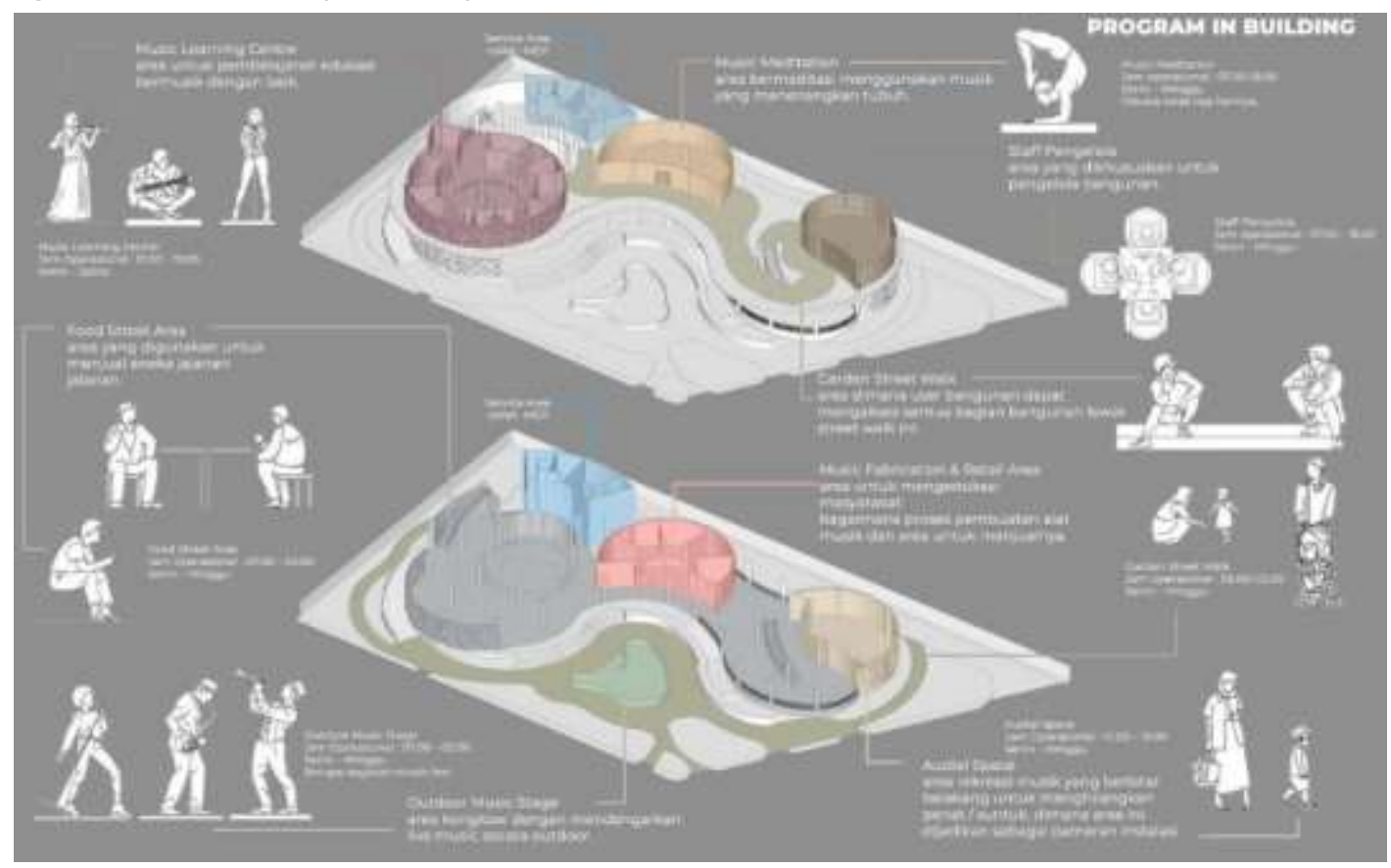

Gambar 8. Programatik Aktivitas pada Bangunan

Sumber : Penulis, 2020

Program yang akan dimasukan kedalam proyek Papanggo's Music Recreation Space in Tanjung Priok ini diantara nya yaitu memasukan terapi secara tak langsung melalui seni musik dengan berbagai wisata yang berbau musik, serta menghadirkan wisata kuliner yang memang menjadi kebutuhan primer bagi manusia. Aktivitas yang akan sangat dominan yakni, aktivitas mendengarkan musik, bernyanyi, memainkan musik, sharing informasi musik, berkumpul dan makan sambil mendengarkan musik. Progam pada proyek ini berupa Music Learning Centre sebagai area edukasi bermusik untuk masyarakat yang ingin belajar dan mengenal cara bermain alat musik. Lalu diikuti adanya food street area yang akan menjual aneka jajanan jalanan serta menjadi wadah sarana untuk memfasilitasi para pedagang kaki lima yang berjualan di daerah pedestrian.

Lalu ada yang namanya Outdoor Music Stage sebagai area untuk berkumpul dan bersenangsenang sambil mendengarkan live music. Ada juga program Music Meditation sebagai area bermeditasi dengan musik yang menenangkan tubuh, diikuti Garden Street Walk dengan konsep infinity loop seakan-akan user diberi pengalaman ruang yang berulang. Terdapat Music Fabrication \& Retail Area dimana area ini sebisa mungkin dapat mengedukasi masyarakat bagaimana proses pembuatan alat musik serta menjadi wadah untuk para penikmat musik menjual alat musik nya. Serta yang terakhir terdapat program berjudul Audial Space yang merupakan area rekreasi musik dengan mengambil latar belakang fungsi menghilangkan penat dan suntuk di tengah aktivitas yang padat. 


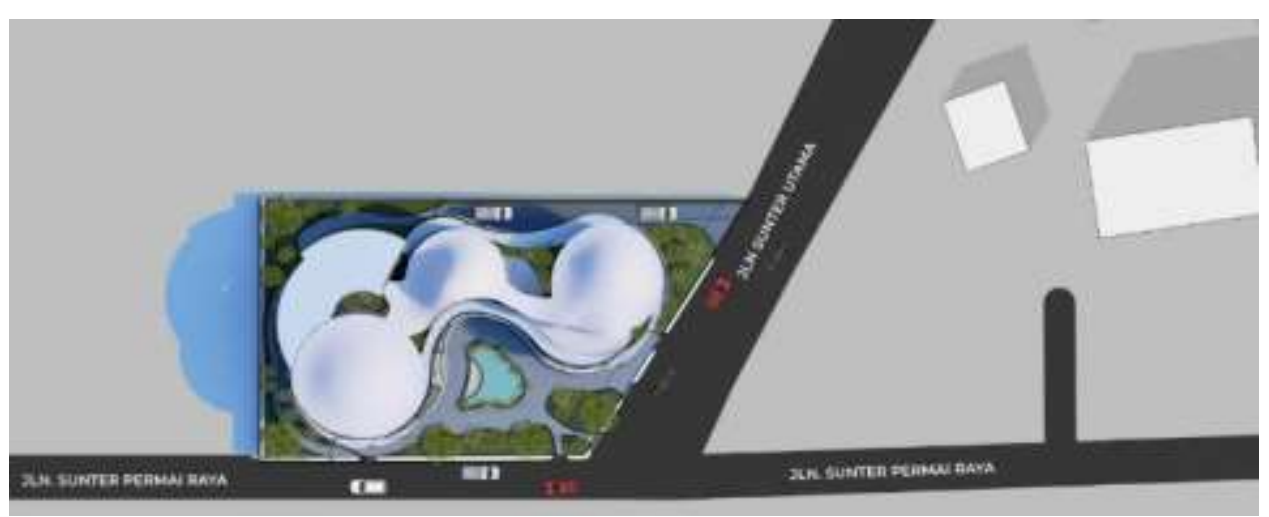

Gambar 9. Site Plan

Sumber : Penulis, 2020

Untuk target user yang ingin dicapai yaitu pengguna Jalan. Utama 1 \& Jalan. Sunter Permai Raya. Dimana jalan utama merupakan daerah hunian perumahan Sunter Permai, sedangkan Jalan. Sunter Permai Raya merupakan akses utama pada daerah Sunter.

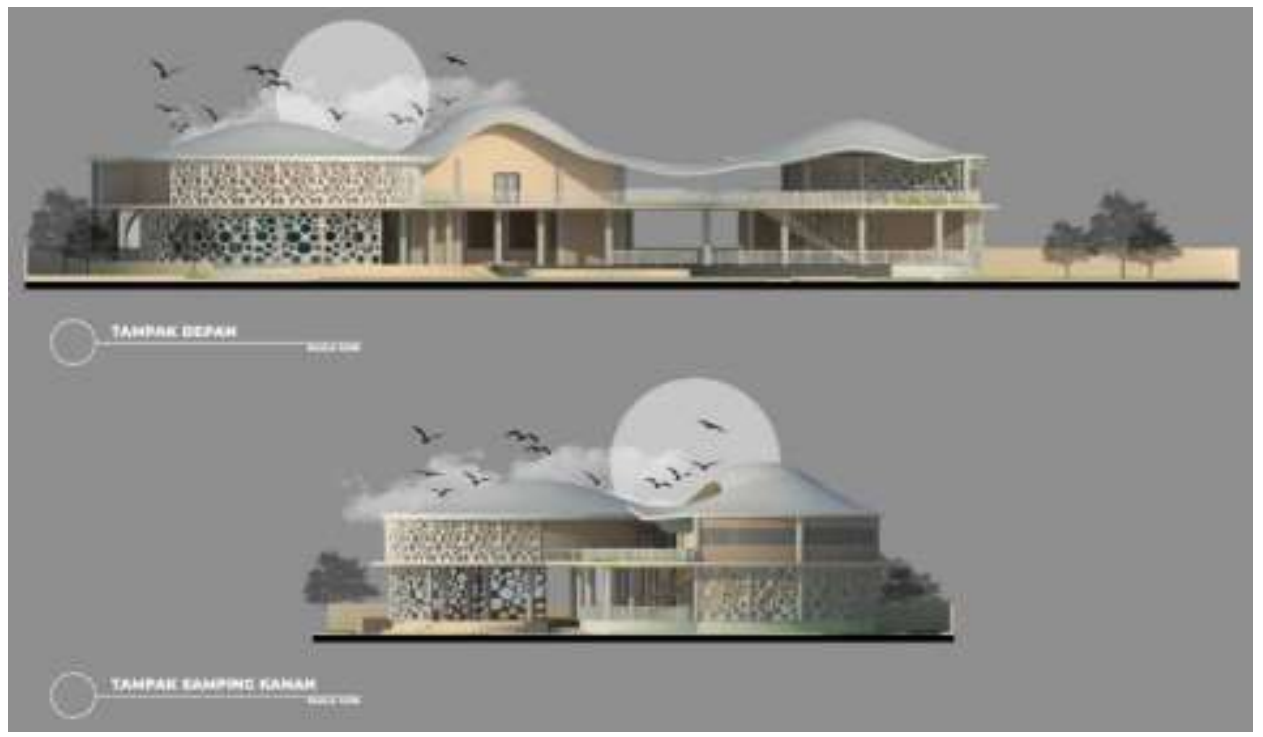

\section{Gambar 10. Tampak Depan \& Samping Kanan}

Sumber : Penulis, 2020

Untuk pemakaian warna pada proyek, didominasi dengan warna coklat dengan penambahan aksen abu dimana dapat menampilkan nilai psikologi dalam suatu seni, warna coklat mempresentasikan poin natural, stabil, \& nyaman , lalu dengan penambahan warna abu yang menambah kesan netral yang menjadii nilai lebih pada bangunan.

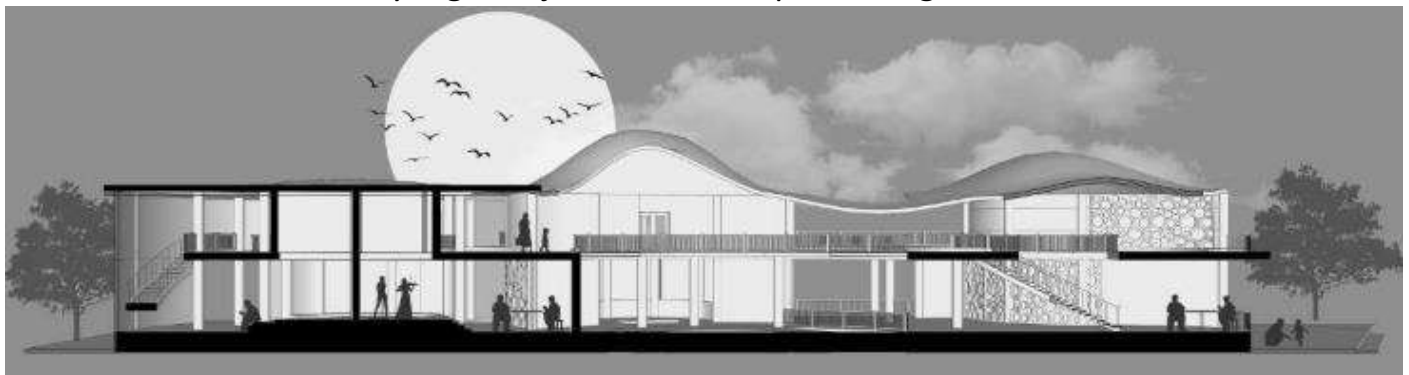

Gambar 11. Skema Aktivitas pada Bangunan

Sumber : Penulis, 2020 


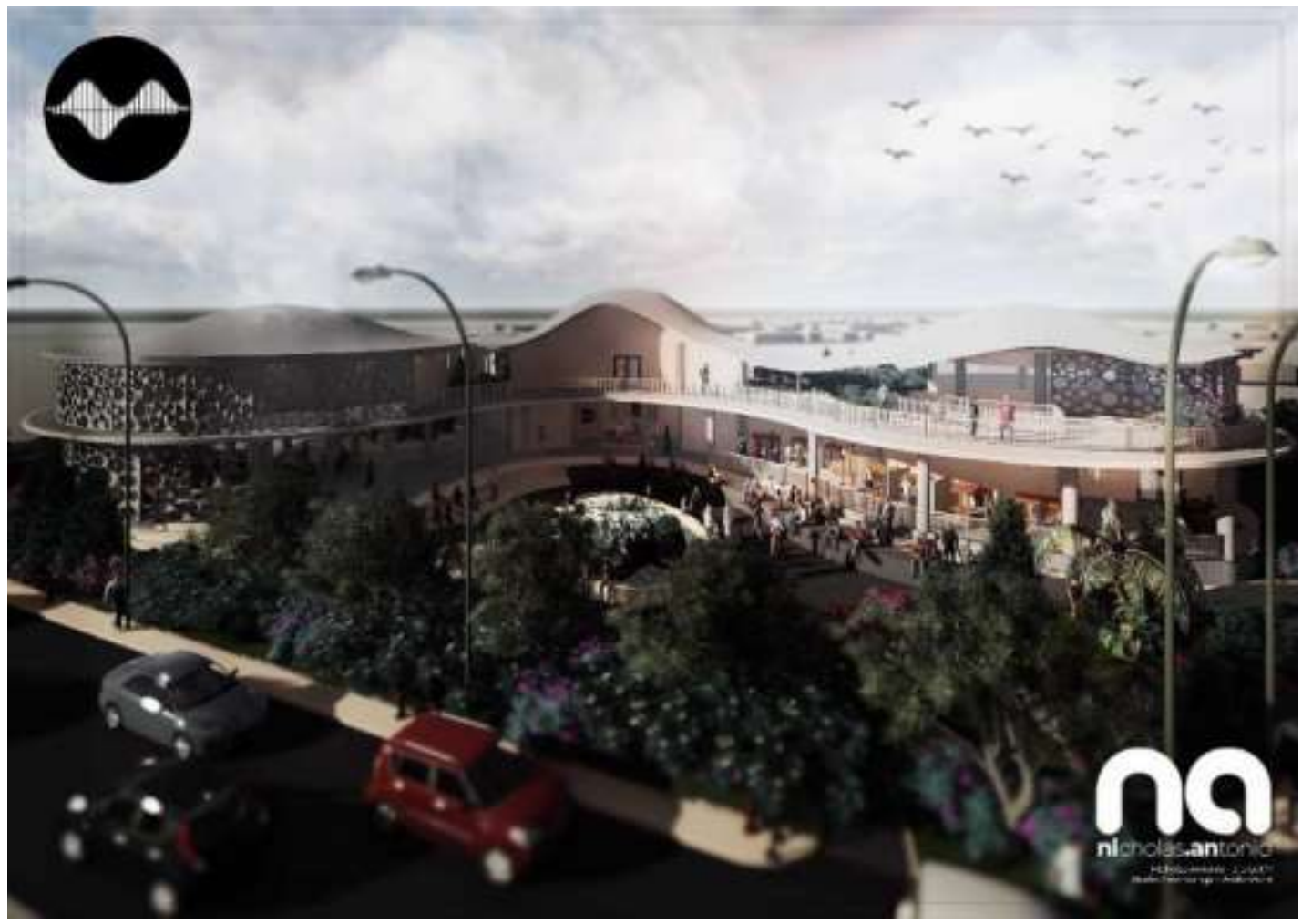

Gambar 12. Exterior 3D Bird Eye View

Sumber : Penulis, 2020

\section{KESIMPULAN DAN SARAN}

\section{Kesimpulan}

Musik merupakan sebuah bahasa yang universal sehingga dapat diterima secara universal. Pengaruh musik terhadap psikologis individu juga perlu dilihat mengingat bahwa musik tidak terlepas dari kehidupan sehari-hari. Hal tersebut berkaitan dengan cara mempersepsi musik dan bagaimana kondisi saat mendengarkannya. Dengan menghadirkan kebersamaan dalam bersosialisasi secara nyata. Third place di dalam konteks open architecture terdapat program utama yang didukung oleh program - program lain yang dimana sebisa mungkin dapat melayani kebutuhan masyarakat kota. Program-program yang ada didalam tapak ditunjukan sebagai respon desain terhadap masalah untuk meningkatkan kesehatan mental yang dialami oleh masyarakat, serta menjawab masalah antara first place dan second place. Selain itu, area kuliner yang berbasis jajanan jalanan sebagai wadah penampung pedagang kaki lima menjadi salah satu program utama yang bisa menjawab masalah terkait kondisi sekitaran tapak. Musik dan kuliner sendiri pada dasarnya sudah menjadi jawaban untuk third place dimana orang-orang bisa berkumpul, bercengkrama, dan melepaskan permasalahan yang terjadi pada first place dan second place. Hal ini juga sudah menjawab pengertian akan recreation dengan upaya merevitalisasi jiwa dan tubuh yang terhindar dari kegiatan rutin dan kondisi yang tertekan dalam kehidupan sehari-hari.

\section{Saran}

Selama penulis melakukan kegiatan studio perancangan ini, Jurusan Arsitektur Universitas Tarumanagara merupakan peranan terpenting dalam kelanjutannya kerja mahasiswa dalam pelaksanaan, dikarenakan mata kuliah studio perancangan 8 ini menjadi peran yang sangat penting untuk melanjutkan jenjang karir ke tingkat selanjutnya dengan sebagai syarat utama untuk lulus dari universitas ini, yang menjadi kewajiban bagi seluruh mahasiswa jurusan Arsitektur. Berikut saran penulis kepada mahasiswa Jurusan Arsitektur Universitas Tarumanagara yang sedang menempuh mata kuliah ini, berdasarkan masalah yang dihadapi 
penulis yaitu, memaksimalkan berbagai informasi dan data - data absolut seperti gambaran umum yang diberikan dosen secara jelas dan sistematis, sehingga tidak banyak mahasiswa yang merasa bingung nantinya pada saat membuat tugas. Serta mahasiswa diharapkan mampu memberikan dukungan terhadap mahasiswa lain yang mengalami kesulitan dalam mencari topik materi tugas akhir ini. Serta jangan lupa untuk bergotong royong agar bisa lulus dengan nilai yang maksimal.

\section{REFERENSI}

Oldenburg, Ray. (1999). The Great Good Place: Cafes, Coffee Shops, Bookstores, Bars, Hair Salons, and Other Hangouts at the Heart of a Community. Hachette Books

Geraldina, A.M. (2017). Terapi Musik: Bebas Budaya atau Terikat Budaya? Buletin Psikologi. 25(1):45-53. DOI: 10.22146/buletinpsikologi.27193

Jencks, C. And Kropf, K.(1997). Theories and manifestoes of contemporary architecture.. London: Academy Editions 